\title{
Relationships between Nut Size, Kernel Quality, Nutritional Composition and Levels of Outcrossing in Three Macadamia Cultivars
}

\author{
Tarran E. Richards ${ }^{1}$, Wiebke Kämper ${ }^{1,2,3}$, Stephen J. Trueman ${ }^{1,3, *}$, Helen M. Wallace ${ }^{1,3}$, \\ Steven M. Ogbourne ${ }^{1} \mathbb{D}$, Peter R. Brooks ${ }^{1}$, Joel Nichols ${ }^{1,3}$ and Shahla Hosseini Bai ${ }^{1,3,4}$ \\ 1 Genecology Research Centre, University of the Sunshine Coast, Maroochydore DC, QLD 4558, Australia; \\ tarran.richards@corteva.com (T.E.R.); w.kaemper@griffith.edu.au (W.K.); \\ helen.wallace@griffith.edu.au (H.M.W.); sogbourn@usc.edu.au (S.M.O.); pbrooks@usc.edu.au (P.R.B.); \\ j.nichols2@griffith.edu.au (J.N.); shossein@usc.edu.au (S.H.B.) \\ 2 Department of Animal Ecology, Evolution and Biodiversity, Ruhr-University Bochum, \\ 44780 Bochum, Germany \\ 3 Environmental Futures Research Institute, School of Environment and Science, Griffith University, Nathan, \\ Brisbane, QLD 4111, Australia \\ 4 School of Health, Medical and Applied Sciences, CQ University, Bundaberg, QLD 4670, Australia \\ * Correspondence: s.trueman@griffith.edu.au; Tel.: +61-7-3735-7719
}

Received: 22 December 2019; Accepted: 10 February 2020; Published: 11 February 2020

\begin{abstract}
Tree nuts play an important role in healthy diets, but their economic value and nutritional quality may be affected by their size and paternity. We assessed relationships between nut size and kernel recovery, the incidence of whole kernels, fatty acid composition and mineral nutrient concentrations in three macadamia cultivars, "Daddow", "816" and "A4". We determined to what extent differences in nut size and quality were the result of different levels of cross- or self-paternity. Small nuts of all cultivars had lower kernel recovery than large nuts, and small nuts provided lower incidence of whole kernels in "Daddow" and "A4". Small kernels had a lower relative abundance of the saturated fatty acid, palmitic acid, in all cultivars and higher relative abundance of the unsaturated fatty acid, oleic acid, in "Daddow" and "A4". Small kernels had higher concentrations of many essential nutrients such as nitrogen and calcium, although potassium concentrations were lower in small kernels. Most nuts arose from cross-pollination. Therefore, nut size and kernel quality were not related to different levels of cross- and self-paternity. Identified cross-paternity was $88 \%, 78 \%$ and $90 \%$, and identified self-paternity was 3\%, $2 \%$ and $0 \%$, for "Daddow", " 816 " and "A4", respectively. Small macadamia kernels are at least as nutritious as large macadamia kernels. High levels of cross-paternity confirmed that many macadamia cultivars are predominantly outcrossing. Macadamia growers may need to closely inter-plant cultivars and manage beehives to maximise cross-pollination.
\end{abstract}

Keywords: breeding system; fatty acids; health; kernels; macadamia; mating system; nutrients; nuts; pollination; self-incompatibility

\section{Introduction}

Tree nuts play an important role in healthy human diets, providing beneficial fatty acids, proteins and essential mineral nutrients [1-3]. Most tree nuts are high in unsaturated fatty acids and low in saturated fatty acids [2-9]. Foods rich in unsaturated fatty acids reduce serum cholesterol and low-density lipoprotein (LDL) cholesterol levels and reduce the risk of cardiovascular disease [2,10-14]. Tree nuts provide high levels of amino acids and non-sodium mineral nutrients, including L-arginine and magnesium, that decrease inflammation, blood pressure and oxidative stress $[2,7,15]$. Tree nuts are 
also a valuable source of calcium, iron and zinc, which can be absorbed insufficiently during phases of high dietary demand such as infancy, childhood, adolescence, pregnancy and breastfeeding [16-21].

The fatty acid composition and nutrient concentrations of tree-nut kernels can vary greatly among cultivars [9,22-28]. Fatty acid composition and nutrient concentrations can also vary within almond or pistachio cultivars because of differences in the pollen parentage of individual kernels [22-25,29,30]. For example, self-pollinated kernels of some almond cultivars have lower oleic:linoleic acid ratios than cross-pollinated kernels [25,29]. In addition, self-pollinated kernels of some almond, chestnut and hazelnut cultivars are smaller than cross-pollinated kernels [22,31-33]. Such effects of the paternal genetic background on the size or quality of the embryo are termed "xenia", and xenic effects are common in fruit and nut crops [34]. Therefore, maximising both yield and human-health benefits may depend upon ensuring high levels of cross-pollination in tree-nut orchards.

Relationships between kernel size, nutritional composition, and cross- or self-paternity are poorly understood for some nuts, including the subtropical tree nut, macadamia (Macadamia integrifolia, $M$. tetraphylla and hybrids). Macadamia flowers are bee-pollinated and partially self-incompatible [35-43]. Manual cross-pollination of macadamia racemes produces more fruit than manual self-pollination [44, 45]. Nut-in-shell (NIS) mass, kernel mass, and the ratio of kernel:shell (i.e., kernel recovery) also vary between macadamia fruit arising from open-pollination and supplementary cross-pollination [45, 46]. The differences in nut quality (of cv. "660") were attributed to differences between self- and cross-pollination [46]. However, subsequent paternity analyses revealed that $80 \%-100 \%$ of nuts in a 27-row single-cultivar block of "A16" trees were cross-pollinated [47] and that $60 \%-100 \%$ of nuts from nine cultivars in a multi-cultivar trial were also cross-pollinated [48]. Therefore, variations in nut and kernel size among pollination treatments in early studies might not have been the result of different levels of self- and cross-pollination. Thus, we currently know very little about how self- and cross-pollination of macadamia flowers affect basic kernel-quality attributes such as kernel mass, kernel recovery, and the incidence of whole kernels. We also know very little about how pollen parentage affects the fatty acid composition and nutrient concentrations of macadamia kernels.

In this study, we selectively sampled small and large nuts from three macadamia cultivars, hypothesising that small nuts had arisen from self-pollination, whereas large nuts had arisen from cross-pollination. We determined how nut size was related to kernel recovery, the incidence of whole kernels, fatty acid composition and mineral nutrient concentrations. We then assessed the extent to which differences in nut size and kernel quality were the result of different levels of crossand self-paternity.

\section{Results and Discussion}

\subsection{Kernel Recovery and Incidence of Whole Kernels}

Small nuts of all three cultivars had lower kernel mass and kernel recovery than large nuts (Table 1). These relationships between nut and kernel parameters are consistent with previous results within cultivars "A4", "246" and "660" [45,46]. Strong positive correlations have also been found between nut mass and kernel mass across macadamia cultivars, although non-significant or negative correlations have been detected between nut mass and kernel recovery [49,50]. The average kernel recovery from Australian macadamia orchards is approximately $34 \%$ and growers receive a premium for producing nuts with higher kernel recovery [51,52]. Our results demonstrate that maximising nut size within cultivars can increase kernel yield and kernel value, which could improve financial returns to growers.

Supplementary cross-pollination, compared with open-pollination, has increased kernel recovery previously by $1.5 \%-3.3 \%$ in cultivars " 660 ", " 246 " and "A4" $[45,46]$. These increases are similar to the differences we detected between small and large nuts (Table 1). The final sizes of the macadamia kernel and nut-in-shell are determined halfway through fruit development when the shell hardens after the rapid growth of the endosperm and embryo [53-58]. The endosperm and embryo, which comprise the 
immature kernel, are both progeny tissues (i.e., combining maternal and paternal alleles) and so it was possible that kernel size was affected directly by fruit paternity $[58,59]$.

Table 1. Relationships between nut size, kernel size, kernel recovery, and incidence of whole kernels in macadamia cultivars, "Daddow", "816" and "A4", each sampled at one of two commercial orchard sites.

\begin{tabular}{|c|c|c|c|c|c|c|}
\hline & \multicolumn{6}{|c|}{ Cultivar and Nut Size } \\
\hline & \multicolumn{2}{|c|}{$\begin{array}{l}\text { "Daddow" } \\
\text { (Site 1) }\end{array}$} & \multicolumn{2}{|c|}{$\begin{array}{l}\text { “816” } \\
\text { (Site 2) }\end{array}$} & \multicolumn{2}{|c|}{$\begin{array}{l}\text { "A4" } \\
\text { (Site 2) }\end{array}$} \\
\hline & Small & Large & Small & Large & Small & Large \\
\hline Nut-in-Shell Mass (g) & $4.75 \pm 0.05 a$ & $8.59 \pm 0.10 \mathrm{~b}$ & $5.17 \pm 0.08 \mathrm{a}$ & $8.79 \pm 0.08 b$ & $6.33 \pm 0.09 a$ & $9.97 \pm 0.27 b$ \\
\hline Kernel Mass (g) & $1.72 \pm 0.03 a$ & $3.31 \pm 0.03 b$ & $2.20 \pm 0.05 a$ & $4.06 \pm 0.04 b$ & $2.65 \pm 0.06 a$ & $4.29 \pm 0.07 \mathrm{~b}$ \\
\hline Kernel Recovery (\%) & $35.9 \pm 0.4 a$ & $38.8 \pm 0.3 \mathrm{~b}$ & $42.5 \pm 0.7 \mathrm{a}$ & $46.2 \pm 0.4 \mathrm{~b}$ & $41.6 \pm 0.8 \mathrm{a}$ & $43.7 \pm 0.6 \mathrm{~b}$ \\
\hline Whole Kernels (\%) & $60.0 \pm 2.4 a$ & $76.0 \pm 3.5 b$ & $79.0 \pm 3.6$ & $82.0 \pm 2.4$ & $64.0 \pm 2.7 \mathrm{a}$ & $72.0 \pm 2.4 \mathrm{~b}$ \\
\hline
\end{tabular}

Means \pm SE with different letters within a cultivar are significantly different (3-way ANOVA for nut-in-shell mass, kernel mass and kernel recovery, and paired $t$-test for whole kernels; $p<0.05, n=237-240$ nuts except $n=6$ trees for whole kernels).

Small "Daddow" and "A4" nuts also yielded a lower percentage of whole kernels than did large nuts (Table 1). The incidence of whole kernels did not differ significantly between small and large nuts of cultivar " 816 " (Table 1). Correlations between whole-kernel incidence and either nut mass, kernel mass or kernel recovery across 40 cultivars have previously been found non-significant [49]. In addition, whole-kernel incidence had not been related previously to nut size within individual cultivars. However, some cultivars such as "A16", "A 38 " and " 816 " that tend to have large kernels and high kernel recovery [60-64] do provide a high percentage of whole kernels [65-67]. Macadamia processors trade kernels under a range of "styles", with the highest-value styles $(0,1$ and 2$)$ comprised predominantly of whole kernels rather than halves or pieces $[67,68]$. Our results further demonstrate that maximising nut size can increase kernel value, which could improve financial returns to macadamia processors.

\subsection{Fatty Acid Composition}

Kernels from small nuts of all three cultivars had a lower relative abundance of the saturated fatty acid (SFA), palmitic acid, than kernels from large nuts (Table 2). These reductions were small ( $0.38 \%$ to $0.76 \%$ relative abundance) and they were offset in " 816 " and "A4" kernels by increases in the relative abundance of another SFA, stearic acid. Kernels of small "Daddow" and "A4" nuts had higher relative abundance of the predominant unsaturated fatty acid (UFA), oleic acid (Table 2). This was offset partly in "Daddow" by lower relative abundance of another UFA, palmitoleic acid (Table 2), of which macadamia is one of the main possible dietary sources [69]. Differences in the relative abundances of other fatty acids were negligible (Table 2). Small "Daddow" kernels had lower total-SFA relative abundance, higher total-UFA relative abundance and, thus, a higher UFA:SFA ratio than large kernels (Table 3). The differences in total-SFA and total-UFA relative abundance were less than $1 \%$ but they could confer a slight health advantage on small "Daddow" kernels because of the beneficial effects of dietary UFAs in regulating lipid levels, maintaining healthy body weight and preventing inflammation $[12,13,18,70]$. Total-SFA relative abundance, total-UFA relative abundance and UFA:SFA ratio did not differ significantly between small and large kernels of "816" or "A4" (Table 3). However, partial replacement of one SFA, palmitic acid, with another SFA, stearic acid, in the small kernels of "816" and "A4" (Table 2) might provide a slight health advantage because palmitic acid increases LDL-cholesterol levels whereas stearic acid does not [13,71].

Our results showed that small macadamia kernels have a fatty acid profile that is at least as healthy as large macadamia kernels. However, the differences in fatty acid profile between small and large kernels were much less than the differences between macadamia cultivars $[27,72,73]$ and between tree-nut species including almond, hazelnut, macadamia, pecan, pistachio and walnut $[4,9]$. All these nuts are considered beneficial for reducing the risk of cardiovascular disease because of their high levels of unsaturated fatty acids $[1,2,7,10,14,74-79]$. 
Table 2. Relationships between nut size and relative abundances (\%) of fatty acids in kernels from macadamia cultivars, “Daddow", "816" and "A4", each sampled at one of two commercial orchard sites.

\begin{tabular}{ccccccc}
\hline Fatty Acid & \multicolumn{7}{c}{ Cultivar and Nut Size } \\
& \multicolumn{2}{c}{$\begin{array}{c}\text { "Daddow" } \\
\text { (Site 1) }\end{array}$} & \multicolumn{2}{c}{$\begin{array}{c}\text { “816" } \\
\text { (Site 2) }\end{array}$} & \multicolumn{2}{c}{$\begin{array}{c}\text { "A4" } \\
\text { (Site 3) }\end{array}$} \\
& Small & Large & Small & Large & Small & Large \\
\hline Myristic Acid (C14:0) & $0.51 \pm 0.02$ & $0.51 \pm 0.02$ & $0.60 \pm 0.02$ & $0.61 \pm 0.02$ & $0.29 \pm 0.01$ & $0.28 \pm 0.01$ \\
Palmitoleic Acid (C16:1 cis) & $17.57 \pm 0.44 \mathrm{a}$ & $19.55 \pm 0.37 \mathrm{~b}$ & $17.18 \pm 0.34$ & $17.38 \pm 0.34$ & $18.38 \pm 0.30$ & $19.10 \pm 0.29$ \\
Palmitic Acid (C16:0) & $9.30 \pm 0.12 \mathrm{a}$ & $10.06 \pm 0.11 \mathrm{~b}$ & $9.75 \pm 0.15 \mathrm{a}$ & $10.26 \pm 0.14 \mathrm{~b}$ & $9.39 \pm 0.11 \mathrm{a}$ & $9.77 \pm 0.10 \mathrm{~b}$ \\
Linoleic Acid (C18:2) & $1.04 \pm 0.05$ & $1.13 \pm 0.06$ & $1.02 \pm 0.05$ & $0.95 \pm 0.04$ & $0.91 \pm 0.04 \mathrm{a}$ & $1.02 \pm 0.03 \mathrm{~b}$ \\
Oleic Acid (C18:1 cis) & $59.93 \pm 0.53 \mathrm{a}$ & $57.14 \pm 0.42 \mathrm{~b}$ & $60.10 \pm 0.39$ & $60.12 \pm 0.44$ & $57.83 \pm 0.37 \mathrm{a}$ & $56.98 \pm 0.36 \mathrm{~b}$ \\
Elaidic Acid (C18:1 trans) & $4.72 \pm 0.10$ & $4.55 \pm 0.09$ & $3.74 \pm 0.07$ & $3.58 \pm 0.06$ & $4.52 \pm 0.09$ & $4.64 \pm 0.08$ \\
Stearic Acid (C18:0) & $3.24 \pm 0.08$ & $3.28 \pm 0.10$ & $3.79 \pm 0.11 \mathrm{a}$ & $3.43 \pm 0.09 \mathrm{~b}$ & $4.76 \pm 0.14 \mathrm{a}$ & $4.34 \pm 0.14 \mathrm{~b}$ \\
Eicosenoic Acid (C20:1) & $1.70 \pm 0.04$ & $1.70 \pm 0.04$ & $1.56 \pm 0.03$ & $1.54 \pm 0.03$ & $1.27 \pm 0.04$ & $1.34 \pm 0.04$ \\
Arachidic Acid (C20:0) & $1.99 \pm 0.04$ & $2.07 \pm 0.04$ & $2.27 \pm 0.05 \mathrm{a}$ & $2.14 \pm 0.03 \mathrm{~b}$ & $2.66 \pm 0.05$ & $2.52 \pm 0.06$ \\
\hline
\end{tabular}

Means \pm SE with different letters within a cultivar are significantly different (3-way ANOVA, $p<0.05$, $n=146-160$ nuts).

Table 3. Relationships between nut size, relative abundances of fatty acids (\%), and fatty acid ratios in kernels from macadamia cultivars, "Daddow", "816" and "A4", each sampled at one of two commercial orchard sites.

\begin{tabular}{|c|c|c|c|c|c|c|}
\hline \multirow[t]{3}{*}{ Fatty Acids } & \multicolumn{6}{|c|}{ Cultivar and Nut Size } \\
\hline & \multicolumn{2}{|c|}{$\begin{array}{l}\text { "Daddow" } \\
\text { (Site 1) }\end{array}$} & \multicolumn{2}{|c|}{$\begin{array}{c}\text { "816" } \\
\text { (Site 2) }\end{array}$} & \multicolumn{2}{|c|}{$\begin{array}{c}\text { "A4" } \\
\text { (Site 3) }\end{array}$} \\
\hline & Small & Large & Small & Large & Small & Large \\
\hline Saturated (\%) & $15.05 \pm 0.16 a$ & $15.93 \pm 0.14 b$ & $16.41 \pm 0.20$ & $16.43 \pm 0.20$ & $17.06 \pm 0.18$ & $16.92 \pm 0.21$ \\
\hline Unsaturated (\%) & $84.95 \pm 0.16 a$ & $84.07 \pm 0.14 b$ & $83.60 \pm 0.20$ & $83.57 \pm 0.20$ & $82.94 \pm 0.18$ & $83.08 \pm 0.21$ \\
\hline Unsaturated:Saturated & $5.70 \pm 0.07 a$ & $5.31 \pm 0.05 b$ & $5.18 \pm 0.10$ & $5.15 \pm 0.08$ & $4.91 \pm 0.06$ & $4.98 \pm 0.07$ \\
\hline
\end{tabular}

Means \pm SE with different letters within a cultivar are significantly different (3-way ANOVA, $p<0.05$, $n=146-160$ nuts).

\subsection{Mineral Nutrient Concentrations}

Kernels from small nuts had higher concentrations of many mineral nutrients than those from large nuts (Table 4). Nutrient concentrations were similar to standard levels for unroasted macadamia kernels [80] although copper concentrations, not surprisingly, were low for kernels produced on the coastal dermosol and kandosol soils of Sites 1 and 2 and manganese levels were low, especially for kernels produced on the kandosol soil at Site 2 [81]. The total contents of each of the 13 nutrients were always lower in kernels from small nuts than large nuts (data not presented). Nitrogen concentrations were $6 \%-8 \%$ higher in kernels from small nuts (Table 4 ). Nitrogen concentrations are correlated with protein concentrations in plant-foodstuffs [82], and nuts are often consumed as an important source of protein [21,83-85]. Small kernels had 20\%-29\% higher calcium concentrations than large kernels (Table 4). Small kernels also had 22\% and 14\% higher iron concentrations than large kernels in "Daddow" and "A4", respectively, and 11\% higher zinc concentration than large kernels in "816" (Table 4). Nuts are recommended as a source of calcium, iron and zinc, which are often absorbed in insufficient levels, particularly during infancy, childhood, adolescence, pregnancy and breastfeeding $[16,17,19-21,85-89]$. Magnesium concentrations were 9\% higher in kernels from small nuts than large nuts of "Daddow" and " 816 " (Table 4). Nuts are also considered a good source of magnesium, and higher serum magnesium levels are associated with lower blood pressure, inflammation, vascular calcification and oxidative stress, and reduced risk of cardiovascular disease [2,7,90-92]. Importantly, sodium concentrations did not differ significantly between small and large macadamia kernels (Table 4). Therefore, dietary salt intake would not be affected by the selection of unsalted macadamia based on kernel size, assuming equivalent-mass consumption. 
Table 4. Relationships between nut size and mineral nutrient concentrations ( $\mathrm{mg} / 100 \mathrm{~g})$ in kernels from macadamia cultivars, "Daddow", “816" and "A4", each sampled at one of two commercial orchard sites.

\begin{tabular}{|c|c|c|c|c|c|c|}
\hline \multirow[t]{3}{*}{ Nutrient $^{1}$} & \multicolumn{6}{|c|}{ Cultivar and Nut Size } \\
\hline & \multicolumn{2}{|c|}{$\begin{array}{l}\text { "Daddow" } \\
\text { (Site 1) }\end{array}$} & \multicolumn{2}{|c|}{$\begin{array}{l}\text { “816" } \\
\text { (Site 2) }\end{array}$} & \multicolumn{2}{|c|}{$\begin{array}{l}\text { "A4" } \\
\text { (Site 2) }\end{array}$} \\
\hline & Small & Large & Small & Large & Small & Large \\
\hline $\mathrm{N}$ & $1530 \pm 10 a$ & $1450 \pm 10 \mathrm{~b}$ & $1600 \pm 10 a$ & $1500 \pm 10 b$ & $1540 \pm 10 a$ & $1430 \pm 10 b$ \\
\hline $\mathrm{Al}$ & $0.38 \pm 0.03$ & $0.39 \pm 0.04$ & $0.32 \pm 0.02$ & $0.30 \pm 0.01$ & $0.43 \pm 0.03 a$ & $0.31 \pm 0.01 b$ \\
\hline B & $1.08 \pm 0.06 a$ & $0.93 \pm 0.03 b$ & $0.77 \pm 0.04$ & $0.77 \pm 0.04$ & $1.10 \pm 0.06 a$ & $0.88 \pm 0.04 b$ \\
\hline $\mathrm{Ca}$ & $53.07 \pm 1.73 a$ & $44.39 \pm 1.38 b$ & $59.03 \pm 1.74 a$ & $48.54 \pm 1.24 \mathrm{~b}$ & $74.59 \pm 2.06 a$ & $57.92 \pm 1.22 b$ \\
\hline $\mathrm{Cu}$ & $0.28 \pm 0.01 a$ & $0.25 \pm 0.01 b$ & $0.37 \pm 0.01 \mathrm{a}$ & $0.33 \pm 0.01 b$ & $0.35 \pm 0.01$ & $0.33 \pm 0.01$ \\
\hline $\mathrm{Fe}$ & $3.04 \pm 0.09 a$ & $2.49 \pm 0.07 \mathrm{~b}$ & $2.30 \pm 0.09$ & $2.08 \pm 0.08$ & $2.26 \pm 0.12 a$ & $1.97 \pm 0.04 b$ \\
\hline K & $404.99 \pm 8.97 a$ & $439.90 \pm 8.40 \mathrm{~b}$ & $368.80 \pm 6.26 a$ & $403.71 \pm 6.69 b$ & $370.95 \pm 8.65 a$ & $423.04 \pm 7.04 b$ \\
\hline $\mathrm{Mg}$ & $145.05 \pm 2.12 a$ & $130.77 \pm 1.88 b$ & $128.82 \pm 1.96 a$ & $117.81 \pm 1.53 \mathrm{~b}$ & $119.27 \pm 1.95$ & $115.50 \pm 1.63$ \\
\hline $\mathrm{Mn}$ & $2.58 \pm 0.11 \mathrm{a}$ & $1.93 \pm 0.08 \mathrm{~b}$ & $0.52 \pm 0.03$ & $0.48 \pm 0.02$ & $0.64 \pm 0.03 a$ & $0.56 \pm 0.03 b$ \\
\hline $\mathrm{Na}$ & $6.11 \pm 0.41$ & $5.90 \pm 0.39$ & $7.53 \pm 0.42$ & $8.02 \pm 0.41$ & $8.87 \pm 0.97$ & $8.75 \pm 0.94$ \\
\hline $\mathrm{P}$ & $261.84 \pm 3.27 a$ & $245.23 \pm 2.94 b$ & $234.35 \pm 3.05 a$ & $205.03 \pm 3.05 b$ & $234.68 \pm 3.80 a$ & $221.86 \pm 3.26 b$ \\
\hline $\mathrm{S}$ & $142.49 \pm 2.06 a$ & $131.78 \pm 1.83 b$ & $132.61 \pm 2.24 a$ & $113.53 \pm 2.22 b$ & $157.16 \pm 2.49 a$ & $150.69 \pm 1.88 b$ \\
\hline $\mathrm{Zn}$ & $1.79 \pm 0.04$ & $1.81 \pm 0.05$ & $1.44 \pm 0.05 a$ & $1.29 \pm 0.04 b$ & $1.68 \pm 0.06$ & $1.64 \pm 0.05$ \\
\hline
\end{tabular}

${ }^{1}$ Nitrogen $(\mathrm{N})$, aluminium (Al), boron (B), calcium $(\mathrm{Ca})$ copper $(\mathrm{Cu})$, iron $(\mathrm{Fe})$, potassium $(\mathrm{K})$, magnesium $(\mathrm{Mg})$, manganese $(\mathrm{Mn})$, sodium $(\mathrm{Na})$, phosphorous $(\mathrm{P})$, sulphur $(\mathrm{S})$, zinc $(\mathrm{Zn})$. Means $\pm \mathrm{SE}$ with different letters within a cultivar are significantly different (3-way ANOVA, $p<0.05, n=237-240$ nuts).

Potassium concentrations, in contrast to the other mineral nutrients, were lower (by $8 \%-12 \%$ ) in kernels from small nuts (Table 4). These results might relate to the phloem mobility of potassium. Fruit calcium concentrations are often strongly negatively related to fruit mass whereas potassium concentrations are often more-weakly negatively related, or not related significantly, to fruit mass [93-97]. However, positive relationships between fruit potassium concentration and fruit mass have sometimes been detected in apple and avocado [94,95]. These relationships were largely between mineral nutrient concentrations and mass of maternal flesh tissue (i.e., non-embryonic tissue) whereas the current relationships in macadamia kernels relate entirely to embryonic tissue.

\subsection{Levels of Cross- and Self-Paternity}

Both small and large macadamia nuts arose mostly from cross-pollination (Table 5). The overall levels of cross-paternity were at least $88 \% \pm 2 \%, 78 \% \pm 2 \%$ and $90 \% \pm 1 \%$ for "Daddow", " 816 " and "A4", respectively. Identified levels of self-paternity were $3 \% \pm 1 \%, 2 \% \pm 1 \%$ and $0 \%$ for the same respective cultivars. Therefore, differences in kernel recovery, whole-kernel incidence, fatty acid composition and mineral nutrient concentrations were not due to differences in the levels of cross- or self-paternity, as both small and large nuts were mostly cross-pollinated. The high levels of cross-paternity in mature nuts were surprising because macadamia flowers are only partially self-incompatible [37,44-46,98]. Self-pollen tubes are often arrested in the upper style of macadamia flowers whereas cross-pollen tubes have a higher likelihood of penetrating to the lower style and initiating fruit set $[35,37,99]$. Most initially-set fruit abscise during the first half of the fruit development period $[46,55,57,100]$ and so it is possible that self-pollinated fruit are shed selectively during this period of immature fruit drop [101-103].

The high level of cross-paternity in "Daddow" was particularly interesting because "Daddow" nuts were sampled in the middle of a 48 -row single-cultivar block. Here, at least $88 \%$ of nuts were fathered by trees that were at least $200 \mathrm{~m}$ away. These results extend previous findings that $85 \%-90 \%$ of nuts in the middle of a 27-row block of "A16" trees arose from cross-pollination [47]. In that case, most nuts were fathered by trees that were at least $98 \mathrm{~m}$ away. More recently, $60 \%-100 \%$ of nuts from nine different cultivars in a closely-interplanted multi-cultivar trial were found to be cross-pollinated, with nuts of five of these cultivars, "A16", A4", "246", "344" and "800", displaying $100 \%$ cross-paternity [48]. These results, in combination, demonstrate that the realised mating system of many macadamia cultivars is predominantly outcrossing. It remains possible that some cultivars may 
have lower levels of outcrossing, in which case further research could determine whether nuts arising from cross- and self-pollination differ in their nut size, kernel quality and nutritional composition.

Table 5. Relationships between nut size and identified levels of cross- and self-paternity in macadamia cultivars, "Daddow", "816" and "A4", each sampled at one of two commercial orchard sites.

\begin{tabular}{ccccccc}
\hline Paternity & \multicolumn{3}{c}{ Cultivar and Nut Size } \\
\hline & \multicolumn{2}{c}{ “Daddow" } & \multicolumn{2}{c}{ “816" } & \multicolumn{2}{c}{ "A4" } \\
& (Site 1) & \multicolumn{2}{c}{ (Site 2) } & Small & Large \\
\hline Cross (\%) & $93 \pm 2$ & $82 \pm 3$ & $80 \pm 2$ & $75 \pm 3$ & $89 \pm 2$ & $91 \pm 2$ \\
Self (\%) & $5 \pm 2$ & $2 \pm 1$ & $4 \pm 2$ & 0 & 0 & 0 \\
\hline
\end{tabular}

Means \pm SE between small and large nuts within a cultivar do not differ significantly (paired $t$-test, $p>0.05, n=6$ trees). Remaining nuts could not be assigned as either cross- or self-pollinated with a strict ( $95 \%$ ) level of confidence.

The finding that many macadamia cultivars are predominantly outcrossing has enormous implications for the management and design of macadamia orchards. Few macadamia growers rank pollination as a major factor that limits production, with most Australian growers nominating more-clearly observable factors such as storm and hail damage, pest outbreaks, and hot or dry weather [52]. Macadamia cultivars are rarely inter-planted within the same rows in orchards. Instead, orchards are typically established with a system of single-cultivar blocks [40,47] that could be, for example, 5 rows wide (as at Site 2) or 48 rows wide (as at Site 1). However, macadamia flowers are bee-pollinated $[36,38,40-43,45,98]$ and we have demonstrated that nut production is almost totally reliant on the transfer of pollen from one cultivar to another. Therefore, there is the potential for yield to decline with increasing distance from bee hives [104-106] or with increasing distance from another cultivar, as found previously in a 27-row block of "A16" trees [40,47].

\section{Materials and Methods}

\subsection{Study Sites}

We sampled nuts from two commercial macadamia orchards near Bundaberg, Queensland, Australia. Bundaberg has a humid subtropical climate with wet summers and dry winters, mean annual rainfall of $1009.5 \mathrm{~mm}$, and mean minimum-maximum temperatures of $21.5-30.4{ }^{\circ} \mathrm{C}$ in January and $10.3-22.3^{\circ} \mathrm{C}$ in July [107]. Site 1 ( $\left.24^{\circ} 47^{\prime} 53^{\prime \prime} \mathrm{S} 152^{\circ} 17^{\prime} 36^{\prime \prime} \mathrm{E}\right)$ had a red-dermosol soil, while Site $2\left(24^{\circ} 56^{\prime} 6^{\prime \prime}\right.$ $\mathrm{S} 152^{\circ} 21^{\prime} 16^{\prime \prime}$ E) had either a yellow/brown kandosol or a red kandosol soil depending on the location within the orchard [81]. Trees at both sites received fertigation via under-tree sprinklers that were suspended from irrigation pipes. Site 1 contained cultivars "Daddow" and "816", approximately 10 years old, each planted in pure blocks of a single cultivar that were 48 and 42 rows wide, respectively. Rows were $8 \mathrm{~m}$ apart and trees within each row were $4 \mathrm{~m}$ apart. Site 2 contained cultivars, "A4", “A16", “A29", “A38”, “A203”, “A268”, “Daddow", “Own Venture”, “246”, “344”, “660”, “741", “814”, " 816 ", "835", "842" and "849", approximately 13 or 16 years old, depending on location within the orchard. Trees were planted in blocks containing multiple cultivars, with each cultivar occupying five or ten contiguous rows, depending on whether each second row was yet to be removed as the trees aged. Tree spacing was 5 or $10 \mathrm{~m}$ between rows and $2 \mathrm{~m}$ within a row. Sampled trees were in an area where the between-row spacing was now $10 \mathrm{~m}$.

\subsection{Sampling Design, Sample Collection and Processing}

We investigated three cultivars, with each cultivar sampled at one site. Cultivar "Daddow" was sampled at Site 1. Cultivars "816" and "A4" were sampled at Site 2. "Daddow" trees are typically large and rounded, with an open canopy that progresses to a dense canopy with age, and with medium-sized 
nuts [60]. "816" trees are large and upright with a dense canopy and medium to large nuts [60]. "A4" trees are medium-sized with an open spreading habit, and with large to very-large nuts [60].

The middle row of each cultivar was selected to increase the likelihood of finding self-pollinated nuts. We sampled six trees from each cultivar, commencing with the fifth tree from the end of each row at Site 1 and the twentieth tree from the end of each row at Site 2, and then sampling every tenth tree. We collected samples from the orchard floor under each tree on two occasions during the harvest season of each orchard. "Daddow" nuts were collected at Site 1 on 26 Mar 2018 and 18 Apr 2018. Cultivar "816" and "A4" nuts were collected at Site 2 on 27 Mar 2018 and 10 May 2018.

We dehusked the fruit from each sampled tree before drying the nuts at $37^{\circ} \mathrm{C}$ for $2 \mathrm{~d}, 45^{\circ} \mathrm{C}$ for 2 $\mathrm{d}$ and $57^{\circ} \mathrm{C}$ for $2 \mathrm{~d}$ [108]. Non-commercial nuts that were too small to be cracked using commercial crackers ( $<18 \mathrm{~mm}$ in diameter) were excluded. The remaining nuts from each harvest were sorted into two size categories, selecting the ten smallest nuts and the ten largest nuts based on visual examination of nut diameter. This resulted in a total of 240 nuts ( 6 trees $\times 2$ harvests $\times 2$ sizes $\times 10$ nuts) from each cultivar.

We recorded nut-in-shell (NIS) mass for each nut, before cracking it using a manual nutcracker (T.J's, Morayfield, Australia). Kernel mass, and whether the kernel remained whole or split into halves, was also recorded. Kernel recovery was calculated as the percentage of NIS that was comprised of kernel. Each individual kernel was then crushed and dissected into three representative sub-samples of at least: (a) $500 \mathrm{mg}$ for fatty acid analysis; (b) $300 \mathrm{mg}$ for mineral nutrient analysis; and (c) $30 \mathrm{mg}$ for paternity analysis.

\subsection{Fatty Acid Analysis}

We analysed fatty acids as their methyl esters from 154 "Daddow", 146 "816", and 160 "A4" kernels. The first 144 kernels of each cultivar were selected randomly, and additional kernels were selected based on known paternity (see Section 3.5, below). The sub-sample of crushed dried kernel was crushed further to extract oil. Crushed sub-samples were added to $25 \mathrm{~mL}$ of pentane, magnetically stirred for $15 \mathrm{~min}$, and then centrifuged for $5 \mathrm{~min}$ at $2500 \mathrm{rpm}$ to remove suspended solids from the pentane. Pentane was evaporated from the oil using an air-tight vacuum rotator for 5-10 $\mathrm{min}$. The extracted oil was stored in glass vials at $4{ }^{\circ} \mathrm{C}[6]$.

We added $0.7 \mathrm{~mL}$ of anhydrous methanol dibutyl hydroxytoluene solution $(0.015 \%, v / v)$ and $25 \mu \mathrm{L}$ of $\operatorname{HCl}(32 \%, v / v)$ to $1 \mu \mathrm{L}$ of the extracted oil. The mixture was incubated for at least $20 \mathrm{~h}$ at $65^{\circ} \mathrm{C}$ before adding $0.5 \mathrm{~mL}$ of hexane and $0.5 \mathrm{~mL}$ of deionised water and shaking for $30 \mathrm{sec}$. The layer of deionised water was removed manually before adding another $0.5 \mathrm{~mL}$ of deionised water to the hexane. The layer of deionised water was removed, and anhydrous $\mathrm{Na}_{2} \mathrm{SO}_{4}$ was added to remove any remaining water from the hexane. The hexane was removed, avoiding disruption of the $\mathrm{Na}_{2} \mathrm{SO}_{4}$ residue, and fatty acids were analysed by gas chromatography-mass spectrometry (GC-MS; PerkinElmer Clarus 580 GC coupled to a PerkinElmer Clarus SQ8S MS) (Waltham, MA, USA) [3]. The GC column was an Elite-5MS $(30 \mathrm{~m} \times 0.25 \mathrm{~mm} \times 0.25 \mu \mathrm{m})$. The helium carrier gas had a constant flow of $1 \mathrm{~mL} / \mathrm{min}$. The injection port was at $260^{\circ} \mathrm{C}$ with a split ratio of $50: 1$. The temperature program was $50{ }^{\circ} \mathrm{C}$ for $0.5 \mathrm{~min}$, ramping at $10{ }^{\circ} \mathrm{C} / \mathrm{min}$ until $300{ }^{\circ} \mathrm{C}$, and holding for $1.0 \mathrm{~min}$. The MS analysed a mass range from 40 to $400(\mathrm{~m} / \mathrm{z})$, from 3.1 to $26.5 \mathrm{~min}$ at $70 \mathrm{eV}$. We identified compounds by comparing retention times with authentic standards and comparing mass spectra against National Institute of Standards and Technology (NIST) (08) MS reference-library matches. Quantitation of each compound was via integration of the peak area at the authentic-standard retention time on the total ion current chromatogram.

\subsection{Mineral Nutrient Analysis}

We determined the concentration of nitrogen $(\mathrm{N})$ by combustion analysis using a LECO CNS 2000 (LECO, Saint Joseph, MI, USA) [109,110]. We determined aluminium (Al), boron (B), calcium (Ca), copper $(\mathrm{Cu})$, iron $(\mathrm{Fe})$, magnesium $(\mathrm{Mg})$, manganese $(\mathrm{Mn})$, phosphorus $(\mathrm{P})$, potassium $(\mathrm{K})$, sodium $(\mathrm{Na})$, 
sulphur (S) and zinc (Zn) concentrations by inductively coupled plasma-atomic emission spectroscopy after nitric and perchloric acid digestion [111,112].

\subsection{Paternity Analysis}

We collected a leaf from each sampled tree, from which an approximately $50 \mathrm{mg}$ subsample was used to confirm cultivar identity. We also identified potential pollen-parent cultivars within $1.5 \mathrm{~km}$ of the study sites, and we collected leaf samples from each of these cultivars. Seventeen cultivars were identified as candidate pollen parents and incorporated into a reference library for paternity assignment. This reference library contained no additional cultivars to those established in the orchard at Site 2; i.e., candidate pollen-parent cultivars were "A4", "A16", "A29", "A38", "A203", "A268", "Daddow", “Own Venture", “246", “344", “660", “741", “814", “816", “835", “842” and "849".

We froze each leaf or kernel subsample in liquid nitrogen and ground it to a powder using an MM2000 TissueLyser (Retsch, Haan, Germany) after adding disposable 0.1 and $2.3 \mathrm{~mm}$ diameter zirconia/silica beads (Daintree Scientific, St. Helens, Tasmania, Australia) [113]. DNA was extracted using a glass-fibre DNA-extraction protocol for plants [114]. DNA of each subsample was amplified at four different microsatellite loci [115] (Table 6) in a Mastercycler (Eppendorf, Hamburg, Germany). The $5^{\prime}$ end of one primer of each primer pair was fluorescently labelled. Multiplex PCR was carried out for microsatellite loci Mac001, Mac002 and Mac005 using a Type-it microsatellite PCR kit (Qiagen, Hilden, Germany). Microsatellite loci were amplified in $12.5 \mu \mathrm{L}$ reaction volumes containing approximately $20 \mathrm{ng}$ DNA template, $0.2 \mu \mathrm{M}$ of each oligonucleotide primer, $1 \times$ Type-it Multiplex PCR Master Mix and $3 \mu \mathrm{L}$ sterile water. Multiplex PCR was performed with initial denaturation at $95^{\circ} \mathrm{C}$ for $5 \mathrm{~min}$, followed by 35 cycles of $95^{\circ} \mathrm{C}$ for $30 \mathrm{~s}, 57^{\circ} \mathrm{C}$ for $1 \mathrm{~min}$ and $72{ }^{\circ} \mathrm{C}$ for $1 \mathrm{~min}$, then final elongation at $60{ }^{\circ} \mathrm{C}$ for $30 \mathrm{~min}$. Samples were maintained at $10^{\circ} \mathrm{C}$. Microsatellite locus Mac006 was amplified in $11.5 \mu \mathrm{L}$ reaction volumes containing approximately $20 \mathrm{ng}$ DNA template, $1.2 \times \mathrm{F} 1$ Taq reaction buffer, 0.02 U F1 Taq (Fisher Biotec, Wembley, Australia), $0.1 \mathrm{mM}$ dNTPs, $2.4 \mathrm{mM} \mathrm{MgCl} 2,0.2 \mu \mathrm{M}$ of each oligonucleotide primer and $6.7 \mu \mathrm{L}$ sterile water. PCR was performed with initial denaturation at 94 ${ }^{\circ} \mathrm{C}$ for $2 \mathrm{~min}$, followed by 35 cycles of $94{ }^{\circ} \mathrm{C}$ for $10 \mathrm{~s}, 55^{\circ} \mathrm{C}$ for $10 \mathrm{~s}$ and $70{ }^{\circ} \mathrm{C}$ for $1 \mathrm{~min}$, then final elongation at $70^{\circ} \mathrm{C}$ for $5 \mathrm{~min}$. Samples were maintained at $10^{\circ} \mathrm{C}$.

Table 6. Polymorphic microsatellite loci used to determine paternity of macadamia kernels ${ }^{1}$.

\begin{tabular}{|c|c|c|c|c|c|}
\hline Locus & & Primer Sequences $\left(5^{\prime}-3^{\prime}\right)$ & Repeat Motif & $\begin{array}{l}\text { Fluorescent } \\
\text { Label }\end{array}$ & $\begin{array}{l}\text { Allele Size } \\
\text { Range (bp) }\end{array}$ \\
\hline Mac001 & $\begin{array}{l}\text { F: } \\
\text { R: }\end{array}$ & $\begin{array}{l}\text { GTGACTGGTGGACACCAAAACCCA } \\
\text { GCACTAGGTGTCACССССАСТTCT }\end{array}$ & $(\mathrm{AT})_{11}$ & VIC & $407-429$ \\
\hline Mac002 & $\begin{array}{l}\text { F: } \\
\text { R: }\end{array}$ & $\begin{array}{l}\text { CCCAACTGGGTTTGCAAGGACCAA } \\
\text { AGTAGCCGCGAGCTGATCGAAGAT }\end{array}$ & $(\mathrm{CT})_{8}$ & NED & $271-313$ \\
\hline Mac005 & $\begin{array}{l}\text { F: } \\
\text { R: }\end{array}$ & $\begin{array}{l}\text { CATAGCATGAGTTTCAAGGGATAA } \\
\text { ATTACAAACCCACTCTTCGATTT }\end{array}$ & $(\mathrm{AAG})_{10}$ & FAM & $255-356$ \\
\hline Mac006 & $\begin{array}{l}\text { F: } \\
\text { R: }\end{array}$ & $\begin{array}{l}\text { TTTCATCATTGATCATCATAGGTACA } \\
\text { GAGCTAATACTTAACCAGGTGAACA }\end{array}$ & $(\mathrm{AG})_{11}$ & PET & $314-368$ \\
\hline
\end{tabular}

We separated the PCR products by agarose gel electrophoresis and viewed them under ultra-violet light on a Gelscan visualiser (Sebia, Lisse, France). PCR products were diluted with molecular-grade water $(1: 19, \mathrm{v}: \mathrm{v})$. The PCR dilution $(1 \mu \mathrm{L})$ was added to a solution containing $9 \mu \mathrm{L}$ Hi-Di and $0.1 \mu \mathrm{L}$ GS-600 LIZ (Applied Biosystems, Foster City, CA, USA) and injected into an AB 3500 Genetic Analyser (Thermo Fisher Scientific, Waltham, MA, USA). We determined allele sizes relative to GS-600 LIZ using GeneMarker v.2.6.3 (SoftGenetics, State College, PA, USA). Scoring was cross-checked manually to ensure accuracy and consistency [116]. We identified two different genotypes in cultivar "A203" and "741" leaf samples and so these were labelled as either "A203_1", "A203_2", “741_1" or "741_2" in the reference library. This provided 19 potential pollen parents for each nut. 
We analysed paternity of kernels by the logarithm of odds (LOD) method using Cervus 2.0 software (Field Genetics Ltd., London, UK). The LOD for each possible pollen parent was calculated by taking the natural log of the overall likelihood ratio. A positive LOD meant that the candidate cultivar was more likely to be the true pollen parent than a cultivar selected randomly from the reference library. Cultivars with a negative LOD were excluded as pollen parents for each kernel. We then assigned nuts as cross- or self-pollinated if all remaining pollen parents were either cross-pollen cultivars or the self-pollen cultivar, respectively. Remaining nuts were then assigned as cross- or self-pollinated if both cross- and self-cultivars were possible pollen parents, but one candidate pollen parent had strict-level confidence ( $95 \%$ ) of the LOD. Kernels were considered "unassigned" if both cross- and self-pollination remained possible but the confidence value for the primary-candidate pollen parent was less than $95 \%$. Kernels were considered "mismatched" if no parent pair from the reference library could explain its genotype.

\subsection{Statistical Analysis}

We analysed data for nut-in-shell mass, kernel mass, kernel recovery, fatty-acid relative abundance, kernel nutrient concentrations and kernel nutrient contents by 3-way analyses of variance (nut size $\times$ harvest time $\times$ tree) using IBM SPSS Statistics v. 25. Nut size $\times$ harvest time and nut size $\times$ harvest time $\times$ tree interactions were generally not significant and so reported data were pooled across the two harvest times. Whole kernel and paternity data were analysed by paired $t$-tests. The data sets had normal distributions and homogeneous variances, and so data transformation was unnecessary. Means and interactions were regarded as significantly different at $p<0.05$. Means are reported with standard errors.

\section{Conclusions}

Small macadamia nuts provided lower kernel recovery and whole-kernel incidence than did large nuts, which reduces their financial value. However, higher mineral nutrient concentrations and more nutritionally-beneficial fatty acid profiles ensured that kernels from small macadamia nuts were at least as healthy in human diets as kernels from large nuts. Relationships between nut size and kernel quality were not the result of differences in cross- and self-paternity levels between small and large nuts. Macadamia trees were predominantly outcrossing. Most nuts of all three cultivars, "Daddow", "816" and "A4", were cross-pollinated, even in the middle of a 48-row block of a single cultivar. Growers might need to consider inter-planting cultivars closely and managing bee hives to maximise the dispersal of pollen from one macadamia cultivar to another.

Author Contributions: Conceptualization, S.H.B., S.J.T., H.M.W., W.K. and T.E.R.; methodology, S.H.B., S.J.T., H.M.W., W.K., S.M.O. and P.R.B.; formal analysis, T.E.R., J.N. and W.K.; writing-original draft preparation, T.E.R.; writing-review and editing, S.J.T., S.H.B., W.K., H.M.W., S.M.O., P.R.B. and J.N.; supervision, S.H.B., S.J.T., W.K. and H.M.W.; funding acquisition, S.J.T., H.M.W., S.H.B., S.M.O., W.K. and T.E.R. All authors have read and agreed to the published version of the manuscript.

Funding: W.K. was supported by the Ruhr University Research School through Germany's Excellence Initiative [DFG GSC 98/3]. T.E.R. was supported by a Vice Chancellor's Honours Scholarship from the University of the Sunshine Coast (USC). Nutrient analyses were funded by Project PH16001 of the Hort Frontiers Pollination Fund, part of the Hort Frontiers strategic partnership initiative developed by Hort Innovation, with co-investment from USC, Plant \& Food Research Ltd. and contributions from the Australian Government.

Acknowledgments: We thank Duane Joyce, Ray Norris, Ngarie Myers and Johan Oosthuizen for assistance and access to their orchards, and Chris Searle for advice and assistance. We thank Tracey McMahon, Brittany Elliott, Tsvakai Gama, Darren Morrow, Michael Nielsen and David Appleton for assistance.

Conflicts of Interest: The authors declare no conflict of interest. The funders had no role in the design of the study; in the collection, analyses, or interpretation of data; in the writing of the manuscript, or in the decision to publish the results. 


\section{References}

1. Souza, R.G.M.; Schincaglia, R.M.; Pimentel, G.D.; Mota, J.F. Nuts and human health outcomes: A systematic review. Nutrients 2017, 9, 1311. [CrossRef] [PubMed]

2. Bitok, E.; Sabaté, J. Nuts and cardiovascular disease. Prog. Cardiovasc. Dis. 2018, 61, 33-37. [CrossRef] [PubMed]

3. Bai, S.H.; Brooks, P.; Gama, R.; Nevenimo, T.; Hannet, G.; Hannet, D.; Randall, B.; Walton, D.; Grant, E.; Wallace, H.M. Nutritional quality of almond, canarium, cashew and pistachio and their oil photooxidative stability. J. Food Sci. Technol. 2019, 56, 792-798. [CrossRef] [PubMed]

4. Kornsteiner-Krenn, M.; Wagner, K.-H.; Elmadfa, I. Phytosterol content and fatty acid pattern of ten different nut types. Int. J. Vitam. Nutr. Res. 2013, 83, 263-270. [CrossRef]

5. Aquino-Bolaños, E.N.; Mapel-Velazco, L.; Martín-del-Campo, S.T.; Chávez-Servia, J.L.; Martínez, A.J.; Verdalet-Guzmán, I. Fatty acids profile of oil from nine varieties of Macadamia nut. Int. J. Food Prop. 2017, 20, 1262-1269. [CrossRef]

6. Bai, S.H.; Darby, I.; Nevenimo, T.; Hannet, G.; Hannet, D.; Poienou, M.; Grant, E.; Brooks, P.; Walton, D.; Randall, B.; et al. Effects of roasting on kernel peroxide value, free fatty acid, fatty acid composition and crude protein content. PLOS ONE 2017, 12, e0184279.

7. Kim, Y.; Keogh, J.B.; Clifton, P.M. Benefits of nut consumption on insulin resistance and cardiovascular risk factors: Multiple potential mechanisms of actions. Nutrients 2017, 9, 1271. [CrossRef]

8. Gama, T.; Wallace, H.M.; Trueman, S.J.; Bai, S.H. Variability in crude protein and mineral nutrient concentrations of almonds. Acta Hortic. 2018, 1219, 213-218. [CrossRef]

9. Gama, T.; Wallace, H.M.; Trueman, S.J.; Hosseini-Bai, S. Quality and shelf life of tree nuts: A review. Sci. Hortic. 2018, 242, 116-126. [CrossRef]

10. Garg, M.L.; Blake, R.J.; Wills, R.B.H. Macadamia nut consumption lowers plasma total and LDL cholesterol levels in hypercholesterolemic men. J. Nutr. 2003, 133, 1060-1063. [CrossRef]

11. Hiraoka-Yamamoto, J.; Ikeda, K.; Negishi, H.; Mori, M.; Hirose, A.; Sawada, S.; Kitamori, K.; Onobayashi, Y.; Kitano, S.; Tashiro, M.; et al. Serum lipid effects of a monounsaturated (palmitoleic) fatty acid-rich diet based on macadamia nuts in healthy, young Japanese women. Clin. Exp. Pharmacol. Physiol. 2004, 31, S37-S38. [CrossRef] [PubMed]

12. Sabaté, J.; Oda, K.; Ros, E. Nut consumption and blood lipid levels: A pooled analysis of 25 intervention trials. Arch. Intern. Med. 2010, 170, 821-827. [CrossRef] [PubMed]

13. Billingsley, H.E.; Carbone, S.; Lavie, C.J. Dietary fats and chronic noncommunicable diseases. Nutrients 2018, 10, 1385. [CrossRef] [PubMed]

14. Hong, M.Y.; Groevn, S.; Marx, A.; Rasmussen, C.; Beidler, J. Anti-Inflammatory, antioxidant, and hypolipidemic effects of mixed nuts in atherogenic diet-fed rats. Molecules 2018, 23, 3126. [CrossRef]

15. Hosseini-Bai, S.; Trueman, S.J.; Nevenimo, T.; Hannet, G.; Randall, B.; Wallace, H.M. The effects of tree spacing regime and tree species composition on mineral nutrient composition of cocoa beans and canarium nuts in 8-year-old cocoa plantations. Environ. Sci. Pollut. Res. 2019, 26, 22021-22029. [CrossRef]

16. Collings, R.; Harvey, L.J.; Hooper, L.; Hurst, R.; Brown, T.J.; Ansett, J.; King, M.; Fairweather-Tait, S.J. The absorption of iron from whole diets: A systematic review. Am. J. Clin. Nutr. 2013, 98, 65-81. [CrossRef]

17. Kaganov, B.; Caroli, M.; Mazur, A.; Singhal, A.; Vania, A. Suboptimal micronutrient intake among children in Europe. Nutrients 2015, 7, 3524-3535. [CrossRef] [PubMed]

18. Brown, R.C.; Gray, A.R.; Tey, S.L.; Chisholm, A.; Burley, V.; Greenwood, D.C.; Cade, J. Associations between nut consumption and health vary between omnivores, vegetarians, and vegans. Nutrients 2017, 9, 1219. [CrossRef]

19. Engel, M.G.; Kern, H.J.; Brenna, J.T.; Mitmesser, S.H. Micronutrient gaps in three commercial weight-loss diet plans. Nutrients 2018, 10, 108. [CrossRef]

20. Kim, S.; Fenech, M.F.; Kim, P.-J. Nutritionally recommended food for semi-to strict vegetarian diets based on large-scale nutrient composition data. Sci. Rep. 2018, 8, 4344. [CrossRef]

21. Baroni, L.; Goggi, S.; Battaglino, R.; Berveglieri, M.; Fasan, I.; Filippin, D.; Griffith, P.; Rizzo, G.; Tomasini, C.; Tosatti, M.A.; et al. Vegan nutrition for mothers and children: Practical tools for healthcare providers. Nutrients 2019, 11, 5. [CrossRef] [PubMed] 
22. Kodad, O.; Socias i Company, R. Fruit quality in almond as related to the type of pollination in self-compatible genotypes. J. Am. Soc. Hortic. Sci. 2008, 133, 320-326. [CrossRef]

23. Kodad, O.; Estopañán, G.; Juan, T.; Socias i Company, R. Xenia effects on oil content and fatty acid and tocopherol concentrations in autogamous almond cultivars. J. Agric. Food Chem. 2009, 57, 10809-10813. [CrossRef] [PubMed]

24. Acar, I.; Eti, S. Nut quality of 'Kirmizi', 'Siirt' and 'Ohadi' pistachio cultivars as affected by different pollinators. Acta Hortic. 2011, 912, 81-86. [CrossRef]

25. Alizadeh-Salte, S.; Farhadi, N.; Arzani, K.; Khoshghalb, H. Almond oil quality as related to the type of pollen source in Iranian self-incompatible cultivars. Int. J. Fruit Sci. 2018, 18, 29-36. [CrossRef]

26. Xu, Y.X.; Hanna, M.A. Evaluation of Nebraska hybrid hazelnuts: Nut/Kernel characteristics, kernel proximate composition, and oil and protein properties. Ind. Crops Prod. 2010, 31, 84-91. [CrossRef]

27. O'Hare, T.J.; Trieu, H.H.; Topp, B.; Russell, D.; Pun, S.; Torrisi, C.; Liu, D. Assessing fatty acid profiles of macadamia nuts. HortScience 2019, 54, 633-637. [CrossRef]

28. Oliveira, I.; Meyer, A.S.; Afonso, S.; Aires, A.; Goufo, P.; Trindade, H.; Gonçalves, B. Phenolic and fatty acid profiles, $\alpha$-tocopherol and sucrose contents, and antioxidant capacities of understudied Portuguese almond cultivars. J. Food Biochem. 2019, 43, e12887. [CrossRef]

29. Brittain, C.; Kremen, C.; Garber, A.; Klein, A.-M. Pollination and plant resources change the nutritional quality of almonds for human health. PLoS ONE 2014, 9, e90082. [CrossRef]

30. Rasouli, M.; Imani, A. Effect of supplementary pollination by different pollinizers on fruit set and nut physicochemical traits of 'Supernova', a self-compatible almond. Fruits 2016, 71, 299-306. [CrossRef]

31. Oukabli, A.; Lansari, A.; Walali-Loudiyi, D.E.; Abousalim, A. Effects of controlled self-pollination and cross-pollination on fruit set, embryo viability and pomological traits in the self-compatible almond cv 'Tuono'. Acta Hortic. 2002, 591, 429-435. [CrossRef]

32. Fattahi, R.; Mohammadzedeh, M.; Khadivi-Khub, A. Influence of different pollen sources on nut and kernel characteristics of hazelnut. Sci. Hortic. 2014, 173, 15-19. [CrossRef]

33. Zhang, X.-H.; Yuan, D.-Y.; Zou, F.; Fan, X.-M.; Tang, J.; Zhu, Z.-J. Studies on the pollen xenia of Castanea henryi. Acta Hortic. Sin. 2016, 43, 61-70.

34. Denney, J.O. Xenia includes metaxenia. HortScience 1992, 27, 722-728. [CrossRef]

35. Sedgley, M. Pollen tube growth in macadamia. Sci. Hortic. 1983, 18, 333-341. [CrossRef]

36. Vithanage, H.I.M.V.; Ironside, D.A. The insect pollinators of macadamia and their relative importance. J. Aust. Inst. Agric. Sci. 1986, 52, 155-160.

37. Sedgley, M.; Bell, F.D.H.; Bell, D.; Winks, C.W.; Pattison, S.J.; Hancock, T.W. Self-and cross-compatibility of macadamia cultivars. J. Hortic. Sci. 1990, 65, 205-213. [CrossRef]

38. Heard, T.A. Behaviour and pollinator efficiency of stingless bees and honey bees on macadamia flowers. J. Apic. Res. 1994, 33, 191-198. [CrossRef]

39. Sacramento, C.K.; Pereira, F.M.; Perecin, D.; Sabino, J.C. Capacidade combinatória para fructificação em cultivares de nogueira macadâmia. Pesq. Agropec. Bras. 1999, 34, 2045-2049. [CrossRef]

40. Trueman, S.J. The reproductive biology of macadamia. Sci. Hortic. 2013, 150, 354-359. [CrossRef]

41. Howlett, B.G.; Nelson, W.R.; Pattemore, D.E.; Gee, M. Pollination of macadamia: Review and opportunities for improving yields. Sci. Hortic. 2015, 197, 411-419. [CrossRef]

42. Kaluza, B.F.; Wallace, H.M.; Heard, T.A.; Klein, A.-M.; Leonhardt, S.D. Urban gardens promote bee foraging over natural habitats and plantations. Ecol. Evol. 2016, 6, 1304-1316. [CrossRef]

43. Grass, I.; Meyer, S.; Taylor, P.; Foord, S.; Hajek, P.; Tscharntke, T. Pollination limitation despite managed honeybees in South African macadamia orchards. Agric. Ecosyst. Environ. 2018, 260, 11-18. [CrossRef]

44. Howlett, B.G.; Read, S.F.J.; Alavi, M.; Cutting, B.T.; Nelson, W.R.; Goodwin, R.M.; Cross, S.; Thorp, T.G.; Pattemore, D.E. Cross-Pollination enhances macadamia yields, even with branch-level resource limitation. HortScience 2019, 54, 609-615. [CrossRef]

45. Wallace, H.M.; Vithanage, V.; Exley, E.M. The effect of supplementary pollination on nut set of Macadamia (Proteaceae). Ann. Bot. 1996, 78, 765-773. [CrossRef]

46. Trueman, S.J.; Turnbull, C.G.N. Effects of cross-pollination and flower removal on fruit set in macadamia. Ann. Bot. 1994, 73, 23-32. [CrossRef]

47. Vithanage, V.; Meyers, N.; McConchie, C. Maximising the Benefits from Cross-Pollination in Macadamia Orchards; Horticulture Australia Ltd.: Sydney, Australia, 2002. 
48. Langdon, K.S.; King, G.J.; Nock, C.J. DNA paternity testing indicates unexpectedly high levels of self-fertilisation in macadamia. Tree Genet. Genomes 2019, 15, 29. [CrossRef]

49. Hardner, C.; Winks, C.; Stephenson, R.; Gallagher, E. Genetic parameters for nut and kernel traits in macadamia. Euphytica 2001, 117, 151-161. [CrossRef]

50. O'Connor, K.; Hayes, B.; Hardner, C.; Alam, M.; Topp, B. Selecting for nut characteristics in macadamia using a genome-wide association study. HortScience 2019, 54, 629-632. [CrossRef]

51. Australian Macadamia Society. The Australian Macadamia Industry; Australian Macadamia Society: Lismore, Australia, 2017.

52. Department of Agriculture and Fisheries. Macadamia Industry Benchmark Report. 2009-2018 Seasons; State of Queensland: Brisbane, Australia, 2019.

53. Jones, W.W. A study of developmental changes in composition of the macadamia. Plant Physiol. 1939, 14, 755-768. [CrossRef]

54. Jones, W.W.; Shaw, L. The process of oil formation and accumulation in the macadamia. Plant Physiol. 1943, 18, 1-7. [CrossRef] [PubMed]

55. Sakai, W.S.; Nagao, M.A. Fruit growth and abscission in Macadamia integrifolia. Physiol. Plant. 1985, 64, 455-460. [CrossRef]

56. Nagao, M.A.; Sakai, W.S. Influence of nut age on ethephon-induced abscission of macadamia. Sci. Hortic. 1988, 36, 103-108. [CrossRef]

57. Trueman, S.J.; Turnbull, C.G.N. Fruit set, abscission and dry matter accumulation on girdled branches of macadamia. Ann. Bot. 1994, 74, 667-674. [CrossRef]

58. Herbert, S.W.; Walton, D.A.; Wallace, H.M. Pollen-Parent affects fruit, nut and kernel development of Macadamia. Sci. Hortic. 2019, 244, 406-412. [CrossRef]

59. Herbert, S.W.; Walton, D.A.; Wallace, H.M. The influence of pollen-parent and carbohydrate availability on macadamia yield and nut size. Sci. Hortic. 2019, 251, 241-246. [CrossRef]

60. Vock, N.; Bell, D.; Gallagher, E.; Bryen, L.; McConachie, I.; Firth, D.; O’Hare, P.; Jones, K.; Stephenson, R. Macadamia Variety Identifier; Queensland Department of Primary Industries: Brisbane, Australia, 1999.

61. Trueman, S.J.; Richards, S.; McConchie, C.A.; Turnbull, C.G.N. Relationships between kernel oil content, fruit removal force and abscission in macadamia. Aust. J. Exp. Agric. 2000, 40, 859-866. [CrossRef]

62. Trueman, S.J.; McConchie, C.A.; Turnbull, C.G.N. Ethephon promotion of crop abscission for unshaken and mechanically shaken macadamia. Aust. J. Exp. Agric. 2002, 42, 1001-1008. [CrossRef]

63. Trueman, S.J. Yield responses to ethephon for unshaken and mechanically shaken macadamia. Aust. J. Exp. Agric. 2003, 43, 1143-1150. [CrossRef]

64. Trueman, S.J. Preliminary evaluation of low ethephon doses for inducing fruit abscission of macadamia (Macadamia integrifolia) cv. A16. Trop. Agric. 2003, 80, 243-245.

65. Walton, D.A.; Wallace, H.M. Ultrastructure of Macadamia (Proteaceae) embryos: Implications for their breakage properties. Ann. Bot. 2005, 96, 981-988. [CrossRef] [PubMed]

66. Walton, D.A.; Wallace, H.M.; Webb, R. Ultrastructure and anatomy of Macadamia (Proteaceae) kernels. Aust. J. Bot. 2012, 60, 291-300. [CrossRef]

67. Penter, M.G.; Nkwana, E.; Nxundu, Y. Factors influencing kernel breakage in the South African macadamia industry. S. Afr. Macadamia Grow. Assoc. Yearb. 2008, 16, 6-10.

68. Australian Macadamia Society. Kernel Quality Standard for Processors; Australian Macadamia Society: Lismore, Australia, 2018.

69. Hu, W.; Fitzgerald, M.; Topp, B.; Alam, M.; O'Hare, T.J. A review of biological functions, health benefits, and possible de novo biosynthetic pathway of palmitoleic acid in macadamia nuts. J. Funct. Foods 2019, 62, 103520. [CrossRef]

70. Liu, A.G.; Ford, N.A.; Hu, F.B.; Zelman, K.M.; Mozafarrain, D.; Kris-Etherton, P.M. A healthy approach to dietary fats: Understanding the science and taking action to reduce consumer confusion. Nutr. J. 2017, 16, 53. [CrossRef]

71. Food and Agriculture Organization of the United Nations (FAO). Fats and fatty acids in human nutrition: Report of an expert consultation. FAO Food Nutr. Pap. 2010, 91, 1-166.

72. Kaijser, A.; Dutta, P.; Savage, G. Oxidative stability and lipid composition of macadamia nuts grown in New Zealand. Food Chem. 2000, 71, 67-70. [CrossRef] 
73. Birch, J.; Yap, K.; Silcock, P. Compositional analysis and roasting behaviour of gevuina and macadamia nuts. Int. J. Food Sci. Technol. 2010, 45, 81-86. [CrossRef]

74. Griel, A.E.; Cao, Y.; Bagshaw, D.B.; Cifelli, A.M.; Holub, B.; Kris-Etherton, P.M. A macadamia nut-rich diet reduces total and LDL-cholesterol in mildly hypercholesterolemic men and women. J. Nutr. 2008, 138, 761-767. [CrossRef] [PubMed]

75. Perna, S.; Giacosa, A.; Bonitta, G.; Bologna, C.; Isu, A.; Guido, D.; Rondanelli, M. Effects of hazelnut consumption on blood lipids and body weight: A systematic review and Bayesian meta-analysis. Nutrients 2016, 8, 747. [CrossRef] [PubMed]

76. Bamberger, C.; Rossmeier, A.; Lechner, K.; Wu, L.; Waldmann, E.; Stark, R.G.; Altenhofer, J.; Henze, K.; Parhofer, K.G. A walnut-enriched diet reduces lipids in healthy Caucasian subjects, independent of recommended macronutrient replacement and time point of consumption: A prospective, randomized, controlled trial. Nutrients 2017, 9, 1097. [CrossRef] [PubMed]

77. Atanasov, A.G.; Sabharanjak, S.M.; Zengin, G.; Mollica, A.; Szostak, A.; Simirgiotis, M.; Huminiecki, Ł.; Horbanczuk, O.K.; Nabavi, S.M.; Mocan, A. Pecan nuts: A review of reported bioactivities and health effects. Trends Food Sci. Technol. 2018, 71, 246-257. [CrossRef]

78. Deon, V.; Del Bo, C.; Guaraldi, F.; Abello, F.; Belviso, S.; Porrini, M.; Riso, P.; Guardamagna, O. Effect of hazelnut on serum lipid profile and fatty acid composition of erythrocyte phospholipids in children and adolescents with primary hyperlipidemia: A randomized controlled trial. Clin. Nutr. 2018, 37, 1193-1201. [CrossRef] [PubMed]

79. Kalita, S.; Khandelwal, S.; Madan, J.; Pandya, H.; Sesikeran, B.; Krishnaswamy, K. Almonds and cardiovascular health: A review. Nutrients 2018, 10, 468. [CrossRef] [PubMed]

80. USDA Food Data Central. Nuts, Macadamia Nuts, Raw. Available online: https://fdc.nal.usda.gov/fdc-app. html\#/food-details/170178/nutrients (accessed on 22 January 2020).

81. Soil Survey of the Bundaberg Area, South East Queensland. 2019. Available online: https://publications.qld. gov.au/dataset/soil-survey-bundaberg-bab (accessed on 8 February 2019).

82. Food and Agriculture Organization of the United Nations (FAO). Food Energy-Methods of Analysis and Conversion Factors; Food and Agriculture Organization of the United Nations: Rome, Italy, 2003.

83. Amit, M. Vegetarian diets in children and adolescents. Paediatr. Child Health 2010, 15, 303-314. [PubMed]

84. Marsh, K.A.; Munn, E.A.; Baines, S.K. Protein and vegetarian diets. Med. J. Aust. 2012, 1, 7-10. [CrossRef]

85. Baroni, L.; Goggi, S.; Battino, M. Planning well-balanced vegetarian diets in infants, children, and adolescents: The VegPlate Junior. J. Acad. Nutr. Diet. 2019, 119, 1067-1073. [CrossRef]

86. Borgna-Pignatti, C.; Marsella, M. Iron deficiency in infancy and childhood. Pediatr. Ann. 2008, 37, $329-337$. [CrossRef]

87. Gibson, R.S.; Heath, A.-L.M.; Szymlek-Gay, E.A. Is iron and zinc nutrition a concern for vegetarian infants and young children in industrialized countries. Am. J. Clin. Nutr. 2014, 100, 459S-468S. [CrossRef]

88. Melina, V.; Craig, W.; Levin, S. Position of the Academy of Nutrition and Dietetics: Vegetarian diets. J. Acad. Nutr. Diet. 2016, 116, 1970-1980. [CrossRef]

89. Agnoli, C.; Baroni, L.; Bertini, I.; Ciappellano, S.; Fabbri, A.; Papa, M.; Pellegrini, N.; Sbarbati, R.; Scarino, M.L.; Siani, V.; et al. Position paper on vegetarian diets from the working group of the Italian Society of Human Nutrition. Nutr. Metab. Cardiovasc. Dis. 2017, 27, 1037-1052. [CrossRef] [PubMed]

90. Chrysant, S.G.; Chrysant, G.S. Association of hypomagnesemia with cardiovascular diseases and hypertension. Int. J. Cardiol. Hypertens. 2019, 1, 100005. [CrossRef]

91. Wu, D.; Chen, Y.; Guan, H.; Sun, Y. Association of abnormal serum electrolyte levels with hypertension in a population with high salt intake. Public Health Nutr. 2019, 22, 1635-1645. [CrossRef] [PubMed]

92. Zeper, L.W.; de Baaij, J.H.F. Magnesium and calciprotein particles in vascular calcification: The good cop and the bad cop. Curr. Opin. Nephrol. Hypertens. 2019, 28, 368-374. [CrossRef] [PubMed]

93. Ferguson, I.B.; Watkins, C.B. Crop load affects mineral concentrations and incidence of bitter pit in 'Cox's Orange Pippin' apple fruit. J. Am. Soc. Hortic. Sci. 1992, 117, 373-376. [CrossRef]

94. Volz, R.K.; Ferguson, I.B. Flower thinning method affects mineral composition of 'Braeburn' and 'Fiesta' apple fruit. J. Hortic. Sci. Biotechnol. 1999, 74, 452-457. [CrossRef]

95. Hofman, P.J.; Vuthapanich, S.; Whiley, A.W.; Klieber, A.; Simons, D.H. Tree yield and fruit minerals concentrations influence 'Hass' avocado fruit quality. Sci. Hortic. 2002, 92, 113-123. [CrossRef] 
96. Marques, J.R.; Hofman, P.J.; Wearing, A.H. Between-Tree variation in fruit quality and fruit mineral concentrations of Hass avocados. Aust. J. Exp. Agric. 2006, 46, 1195-1201. [CrossRef]

97. Choi, S.-T.; Ahn, G.-H.; Kim, E.-G.; Son, J.-Y.; Park, Y.-O.; Joung, W.-K. Fruit characteristics and mineral nutrient concentrations depending on different sizes of "Fuyu" persimmon fruits. Agric. Sci. 2019, 10, 1015-1022. [CrossRef]

98. Urata, U. Pollination Requirements of Macadamia; Hawaii Agricultural Experiment Station Technical Bulletin No. 22; Hawaii Agricultural Experiment Station, University of Hawaii: Honolulu, HI, USA, 1954.

99. Sedgley, M.; Blesing, M.A.; Vithanage, H.I.M.V. A developmental study of the structure and pollen receptivity of the macadamia pistil in relation to protandry and self-incompatibility. Bot. Gaz. 1985, 146, 6-14. [CrossRef]

100. Trueman, S.J. Benzyladenine delays immature fruit abscission but does not affect final fruit set or kernel size of Macadamia. Afr. J. Agric. Res. 2010, 5, 1523-1530.

101. Vaughton, G.; Carthew, S. Evidence for selective fruit abortion in Banksia spinulosa (Proteaceae). Biol. J. Linn. Soc. 1993, 50, 35-46. [CrossRef]

102. Korbecka, G.; Klinkhamer, P.G.L.; Vrieling, K. Selective embryo abortion hypothesis revisited-A molecular approach. Plant. Biol. 2002, 4, 298-310. [CrossRef]

103. Alcaraz, M.L.; Hormaza, J.I. Influence of physical distance between cultivars on yield, outcrossing rate and selective fruit drop in avocado (Persea americana, Lauraceae). Ann. Appl. Biol. 2011, 158, 354-361. [CrossRef]

104. Cunningham, S.A.; Fournier, A.; Neave, M.J.; Le Feuvre, D. Improving spatial arrangement of honeybee colonies to avoid pollination shortfall and depressed fruit set. J. Appl. Ecol. 2016, 53, 350-359. [CrossRef]

105. Sáez, A.; Di Virgilio, A.; Tiribelli, F.; Geslin, B. Simulation models to predict pollination success in apple orchards: A useful tool to test management practices. Apidologie 2018, 49, 551-561. [CrossRef]

106. Willcox, B.K.; Robson, A.J.; Howlett, B.G.; Rader, R. Toward an integrated approach to crop production and pollination ecology through the application of remote sensing. PeerJ 2018, 6, e5806. [CrossRef]

107. Climate Statistics for Australian Locations. Available online: http://www.bom.gov.au/climate/averages/ tables/cw_039128.shtml (accessed on 22 January 2020).

108. Meyers, N.M.; Morris, S.C.; McFadyen, L.M.; Huett, D.O.; McConchie, C.A. Investigation of sampling procedures to determine macadamia fruit quality in orchards. Aust. J. Exp. Agric. 1999, 39, 1007-1012. [CrossRef]

109. McGeehan, S.L.; Naylor, D.V. Automated instrumental analysis of carbon and nitrogen in plant and soil samples. Commun. Soil Sci. Plant Anal. 1988, 19, 493-505. [CrossRef]

110. Rayment, G.E.; Higginson, F.R. Australian Laboratory Handbook of Soil and Water Chemical Methods; Inkata: Melbourne, Australia, 1992.

111. Martinie, G.D.; Schilt, A.A. Investigation of the wet oxidation efficiencies of perchloric acid mixtures for various organic substances and the identities of residual matter. Anal. Chem. 1976, 48, 70-74. [CrossRef]

112. Munter, R.C.; Grande, R.A. Plant tissue and soil extract analysis by ICP-atomic emission spectrometry. In Developments in Atomic Plasma Spectrochemical Analysis; Byrnes, R.M., Ed.; Heyden: London, UK, 1981; pp. 653-672.

113. Shapcott, A.; Forster, P.I.; Guymer, G.P.; McDonald, W.J.F.; Faith, D.P.; Erickson, D.; Kress, W.J. Mapping biodiversity and setting conservation priorities for SE Queensland's rainforests using DNA barcoding. PLoS ONE 2015, 10, e0122164. [CrossRef] [PubMed]

114. Ivanova, N.V.; Fazekas, A.J.; Hebert, P.D.N. Semi-Automated, membrane-based protocol for DNA isolation from plants. Plant Mol. Biol. Rep. 2008, 26, 186. [CrossRef]

115. Nock, C.J.; Elphinstone, M.S.; Ablett, G.; Kawamata, A.; Hardner, C.M.; King, G.J. Whole genome shotgun sequences for microsatellite discovery and application in cultivated and wild Macadamia (Proteaceae). Appl. Plant Sci. 2014, 2, 1300089. [CrossRef] [PubMed]

116. Naik, V.M.; Ashwath, N.; Lamont, R.W.; Shapcott, A. Novel microsatellite markers for conservation of Australian native Samadera bidwillii. Open J. Ecol. 2018, 8, 75-85. [CrossRef]

(C) 2020 by the authors. Licensee MDPI, Basel, Switzerland. This article is an open access article distributed under the terms and conditions of the Creative Commons Attribution (CC BY) license (http://creativecommons.org/licenses/by/4.0/). 